\title{
"RESTORATIVE JUSTICE IN MILITARY: PENAL MEDIATION IN THE DISPUTE SETTLEMENT OF TRAFFIC ACCIDENT COMMITTED BY INDONESIAN NATIONAL ARMY."
}

\author{
Ramlani Lina Sinaulan, HanifanHidayatulloh, Yuhelson, Bambang Utoyo \\ Jayabaya University, Jakarta-Indonesia \\ linasinaulan@gmail.com, ifanhanifan70@gmail.comyuhelson@gmail.com, bambangutoyo@gmail.com
}

\begin{abstract}
:
This research attempts to introduce and integrate two relatively foreign concepts to each other; paradigm of restorative justice and military justice system. The aim is simple, namely to explore the extent and under what conditions these two routes of adjudication can function side by side without violating core principles of traditional military justice. This goal implies one important point; not all criminal cases that fall under the jurisdiction of military justice can be resolved using a restorative justice approach. The application of restorative justice in the settlement of traffic accident cases committed by TNI soldiers can only be implemented by reforming the three components of the legal system as stated by Lawrence Friedman, namely legal substance, legal structure and legal culture. Operationally, the application of restorative justice can be carried out in 3 (three) stages, namely investigation, prosecution and trial. However, the application of restorative justice at these three stages is not intended to replace the criminal justice system within the military court, because the restorative justice program is basically complementary and not a substitute for the criminal justice system.
\end{abstract}

Keywords:

Restorative justice, traffic accident crime, legal system of investigation, prosecution and court.

Article Received: 18 October 2020, Revised: 3 November 2020, Accepted: 24 December 2020

\section{INTRODUCTION}

In fact, not a few soldiers of the Indonesian National Army have committed certain crimes that fall into the category of general crimes. One of them is the criminal act of traffic accidents as regulated in Law Number 22 of 2009 concerning Road Traffic and Transportation. A TNI soldier who commits a traffic accident crime will be tried in a military court in accordance with the prevailing laws and regulations. This is regulated in Article 108 paragraph (5) of Law Number 31 Year 1997 concerning Military Courts. Traffic accidents are classified as ordinary offenses so that even though there have been efforts to provide compensation from the perpetrator or reconciliation from both parties, these efforts do not drop the charges of criminal cases (Article 235 Law No. 22/2009). Traffic accident cases must be processed in a criminal

court procedure in accordance with the provisions of laws and regulations (Article 230 of Law No. 22/2009). However, Law no. 22/2009 provides opportunities for perpetrators and victims to make peace outside the court (Article 236 paragraph (2)). This provision basically opens space for case settlement through the penal mediation procedure.

In practice, a traffic accident criminal case can be resolved using the mediation penal procedure. However, this practice is generally only carried out in cases of traffic accidents committed by civilians and handled by the police. On the other hand, traffic criminal cases committed by TNI soldiers are never resolved through penal mediation, but are always pursued through formal judicial procedures. Criminal acts committed by TNI soldiers have very heavy criminal consequences. Apart from being subject to criminal sanctions in the form of basic and additional crimes, TNI soldiers can also be subject to administrative sanctions in the form of suspension of education, promotion of position, 
promotion, and even dismissal. The very heavy norm of criminal responsibility for the TNI who commits this crime needs to be reconsidered. One of the steps that can be taken is to incorporate the dimension of restorative justice into the military justice system, which so far has been heavily associated with traditional command-based approaches. Although the concepts of restorative justice and penal mediation have been well researched in the field of civil criminal justice, academics and military criminal law practitioners tend to ignore the question of the appropriateness of a restorative justice approach for resolving criminal cases committed by members of the military. To date, researchers have not found any research that specifically answers the question of whether the restorative justice paradigm is consistent with the unique military legal culture and military justice system.

The selection on this issue was not without a theoretical basis at all. In this case, the researcher found at least one scientific article that can be used as a theoretical basis for studying the object of research, namely Dan Maurer's (2013) writing entitled "Mediation as Military Justice? Conjectures on Repairing Unit Cohesion in the Wake of Relational Misconduct. " In this paper, Dan Maurer shows that the victim-offender mediation and "administrative mediation" approaches can be applied to resolve military criminal cases that fall into the category of relational crime or misconduct, such as carrying out small attacks between roommates in the barracks, making insults or using offensive language towards a non-commissioned officer, and conveying threats to other members.

The term victim-offender mediation used by Dan Maurer clearly comes from the restorative justice paradigm put forward by contemporary legal experts. Therefore, the researcher argues that Dan Maurer's study can be used as a starting point for examining the application of restorative justice in the settlement of traffic accident cases committed by TNI soldiers. However, it is important to note that Dan Maurer's study only focuses on mediation between members of the military in the context of military crimes and does not discuss mediation between military personnel and civilians in the context of general crimes. In other words, the concept of offender-victim mediation offered by Dan Maurer can only be applied in the context of resolving military crimes, particularly for violations or relational crimes that occur between members of the military. On the other hand, general crimes committed by the military, including traffic accidents, do not only involve victims from the military, but often involve civilian victims. Therefore, a different perpetrator-victim mediation model is needed from the model offered by Dan Maurer, because in the settlement of general criminal cases involving military perpetrators and civilian victims, the parties involved are of different social status. This difference in social status between military and civilian must be carefully considered in the formulation of the perpetrator-victim mediation model so that the psychological and sociological constraints caused by these differences can be minimized in the mediation process.

This research attempts to introduce and integrate two relatively foreign concepts to each other; paradigm of restorative justice and military justice system. The aim is simple, namely to explore the extent and under what conditions these two routes of adjudication can function side by side without violating core principles of traditional military justice. This goal implies one important point; not all criminal cases that fall under the jurisdiction of military justice can be resolved using a restorative justice approach. Therefore, the researchers deliberately chose classes of offenses or crimes that might be resolved through a restorative justice approach, namely general crimes committed by the military. In this research, general criminal acts are limited to traffic accidents.

The question to be answered in this research is: "How is the application of restorative justice in the settlement of traffic crimes 
committed by soldiers of the Indonesian National Army".

\section{RESEARCH METHODS}

To answer the questions above, the researchers used the theory of legal equality, legal systems and restorative justice as analysis tools. Methodologically, this research uses the juridicalnormative method which relies on primary sources or authorities, secondary source or authorities and tertiary source or authorities. The legal materials were analyzed using interpretive methods.

\section{DISCUSSION}

The Application of Restorative Justice in the Settlement of Criminal Cases of Traffic Accidents Committed by TNI Soldiers

Traffic accidents committed by TNI soldiers are always resolved through formal judicial procedures. To date, not a single case has ever been resolved through a penal mediation procedure outside the court. On the other hand, traffic accidents committed by civilians can be resolved through a penal mediation procedure based on police discretion. In theory, differences in treatment between civilians and TNI soldiers are not in line with the principle of equality before the law because TNI soldiers are not given equal opportunity to settle traffic accident criminal cases through the penal mediation channel as provided to civilians.

In contemporary legal literature, the concept of legal equality is classified into two categories, namely formal equality and substantive equality. The concept of formal equality refers to Aristotle's classical thinking about numerical equality. This approach is reflected in the formula: treat the same cases in the same way. According to Paul Stancil (2007) this approach, a legal system can only be justified morally if the system punishes an action in the same way every time the action is carried out by the perpetrator regardless of individual differences. In other words, "the law must judge people for what they have done, not because of who they are." On the other hand, the concept of substantive equality refers to Aristotle's classical thinking about "proportional equality". This approach is reflected in the formula: "treat the same case in different ways to achieve the same result." According to this approach, law, under certain circumstances, must treat people in different ways because of their differences in social structures. That is, unequal treatment can be permitted or necessary to achieve the same result. Therefore, this approach justifies positive action or affirmative action. This kind of substantive concept of equality is known as equality of result. Apart from equality of results, the substantive equality approach also offers an "equal opportunity" model. According to this model, efforts to achieve equality require certain steps to be taken in order to ensure that people from all walks of life have the same opportunity to gain political, legal and economic access. This model is a popular alternative to the concept of equal treatment and equality of results. This model argues that true equality cannot be achieved if individuals start the race from different starting points. Thus, the equality of opportunity model aims to equalize the starting point, not the end result. This model is closely related to the theory of justice John Rawls (2001) which focuses on the issue of distributive justice.

From a substantive equality perspective, the law enforcement process against TNI soldiers who commit traffic accidents does not fulfill the principle of equality of opportunity. It is called that because TNI soldiers are not given the same opportunities as civilians to settle cases through penal mediation. In other words, TNI soldiers are not given access to restorative justice at all in resolving traffic accidents. Therefore, the researcher argues that TNI soldiers as citizens should be given the same opportunity as civilians to gain access to restorative justice in solving traffic accidents. (Amanda Spies, 2017).

Providing opportunities for TNI soldiers to settle criminal cases of traffic accidents outside of 
formal judicial procedures will realize substantive justice, because in this way TNI soldiers are given the same opportunity as civilians to gain access to restorative justice. Nevertheless, the application of restorative justice in the settlement of cases of traffic accidents committed by TNI soldiers cannot automatically be carried out if they do not meet certain requirements which are the basis or basis for the application of restorative justice. In this regard, researchers have conducted a comparative study of the requirements for the application of restorative justice stipulated by the police, Law no. 11 of 2012 concerning the Juvenile Criminal Justice System, and the United Nations (United Nations).

Based on a comparison of a number of requirements set by the police, Law no. 11 of 2012, and the United Nations, researchers put forward four requirements for the application of restorative justice in the settlement of cases of traffic accidents committed by TNI soldiers. The four requirements are as follows: (1) the perpetrator and victim agree to settle the case peacefully without coercion from any party; (2) the perpetrator commits a traffic accident for the first time; (3) the perpetrator is committed to providing restitution or compensation to the victim; and (4) traffic accident which has been committed is categorized as negligence.

The fourth requirement that the researcher submitted was not contained in the requirements set by the police, Law no. 11 of 2012 and the United Nations. Researchers enter these requirements based on the argument that the concept of negligence in criminal law occupies a dilemma in relation to criminal liability. In the legal science tradition, there is disagreement between "subjectivists" and "objectivists" in understanding the concept of criminal responsibility in cases of negligence.

According to the subjectivist approach, crimes that occur as a result of negligence are excluded from criminal responsibility because the person accused of committing such a crime subjectively does not know the circumstances and consequences of the behavior that causes harm. In this view, inadvertence precludes criminal responsibility. Thus, mens rea for a criminal act is limited to intent (intention) or recklessness (recklessness). This subjectivist approach was represented, among others, by Jerome Hall. According to Hall (1963), criminal law should not punish individuals for negligence because "they do not think at all about their obligations, their dangerous behavior, or any sanctions." He argues that the imposition of punishment for crimes due to negligence will be meaningless and can create injustice (unfairness).

Objectivist groups, on the other hand, often justify the doctrine of criminal responsibility without referring to the moral culpability of the accused, but are subject to legislative intent. According to this approach, it is legislative action that determines the "mental element" required for criminal responsibility, be it subjective intent, negligence, or strict liability. Therefore, (Fletcher, 1978), objectivists tend to understand mens rea in a descriptive or positivistic sense. The objectivist approach represented, among others, by Oliver Holmes. According to Holmes (1971), sentencing an actor who commits a crime due to negligence has great benefits, namely as an example for others. In Holmes's view, sacrificing the individual [the perpetrator] to the extent necessary is a very appropriate step in order to encourage external compliance with the rules.

By considering the two paradigms above, the researcher argues that traffic accidents that occur due to negligence can be resolved using a restorative justice approach. This approach can bridge the subjective paradigm and the objective paradigm of negligence as stated above. On the one hand, this approach acknowledges the subjectivist paradigm which holds that crimes committed as a result of negligence should not be subject to criminal sanctions. On the other hand, this approach also recognizes the objectivist view that the punishment of actors who commit crimes due to negligence is necessary as a means of prevention. However, in a restorative justice 
approach, the form of punishment imposed on perpetrators of crimes due to negligence is not punitive, but reparative and restitutive.

Restorative justice (Kathleen Daly, 2008) includes a variety of practices at various stages of the criminal process, including diversion from court prosecution, actions taken in parallel with court decisions, and meetings between victims and perpetrators in every stage of the criminal process, such as arrest, pre-sentencing, and prison release. Restorative justice can be used by all criminal justice institutions such as the police, prosecutors, courts and correctional institutions. In the context of the criminal justice system, there are at least four main points where the restorative justice process can be carried out, namely: (1) the level of investigation (pre-charge); (2) the rate of prosecution (post-charge / pre-conviction); (3) court level (post-conviction / pre-sentence); and (4) the level of detention (post-sentence / prereintegration).

The application of the principle of restorative justice in the criminal justice system is intended to achieve substantive equality. Adopting substantive values in criminal adjudication can enable the interpretation and application of legal principles that are more aware of their impact on the parties involved. In this sense, restorative justice can be seen as a method that provides an effect on the values of substantive equality, which allows the needs and context of the victim (including the perpetrator) to be considered in reaching a just decision. By considering the principle of restorative justice as part of the judicial landscape, the criminal case settlement process must be directed at efforts to be fair to the perpetrator without treating the victim as an inferior party.

\section{CONCLUSION}

The application of restorative justice in the settlement of traffic accident cases committed by TNI soldiers as stated above is one of the efforts to reform the law (law reform / legal reform) in the military justice environment. It is called this because the concept of restorative justice is basically unknown in the military legal regime and military justice in Indonesia. The idea of implementing restorative justice in the military justice environment is intended to fulfill the objective of providing equal opportunity for TNI soldiers - as civilians - to gain access to restorative justice in solving traffic accidents.

The application of restorative justice in the settlement of traffic accident cases committed by TNI soldiers can only be implemented by reforming the three components of the legal system as stated by Lawrence Friedman (1975), namely legal substance, legal structure and legal culture. Operationally, the application of restorative justice can be carried out in 3 (three) stages, namely investigation, prosecution and trial. However, the application of restorative justice at these three stages is not intended to replace the criminal justice system within the military court, because the restorative justice program is basically complementary and not a substitute for the criminal justice system.

\section{REFERENCES}

[1] Afandi, Fachrizal, "The Discretion of the Police of the Republic of Indonesia, Malang City Resort in the Case of Traffic Accidents", 6: 3 Legal Arena, December 2013.

[2] Al Mahdi (et.al.), "Peace in the Crime of Traffic Accidents", 1: 4 Journal of Law, Graduate School of Syiah Kuala University, November 2013.

[3] Bakker, Mark W., "Repairing the Breach and Reconciling the Discordant: Mediation in the Criminal Justice System", 72: 6 North Carolina Law Review, 1993.

[4] Daly, Kathleen, "Seeking Justice in the 21st Century: Towards an Intersectional Politics of Justice", in: Holly Ventura Miller, Restorative Justice: From Theory to Practice, JAI Press, UK, 2008. 
[5] Davidson, Donald, “Agency," in: Donald Davidson, Essays on Actions and Events, Clareadon Press, Oxford, 1980.

[6] Farelly, Colin, Introduction to Contemporary Political Theory, SAGE Publication, London, 2004.

[7] Fletcher, George P, Rethinking Criminal Law, Little, Brown and Company, Boston, 1978.

[8] Fredman, Sandra, "Providing Equality: Substantive Equality and the Positive Duty to Provide", 21: 2 South African Journal on Human Rights, 2005.

\section{"Substantive Equality}

Revisited", 14: 3 International Journal of Constitutional Law, 2016.

[10] Freeman, Samuel, Rawls, Taylor \& Francis, New York, 2007.

[11] Friedman, Lawrence M., The Legal System: A Social Science Perspective, Russell Sage Foundation, New York, 1975.

[12] Fruchtman, Earl, "Recklessness and the Limits of Mens Rea: Beyond Orthodox Subjectivism (Part I)", 29 Criminal Law Quarterly, 1986-87.

[13] Hall, Jerome, "Negligent Behavior Should Be Excluded From Penal Liability", 63 Columbia Law Review, 1963.

[14] Hallevy, Gabriel, "Therapeutic VictimOffender Mediation Within the Criminal Justice Process: Sharpening the Evaluation of Personal Potential for Rehabilitation While Righting Wrongs Under the ADR Philosophy", 16 Harvard Negotiation Law Review, 2011.

[15] Holmes, Oliver W., Jr., "Theories of Punishment and the External Standard", in: Abraham S. Goldstein \& Joseph Goldstein (eds.), Crime, Law and Society, The Free Press, New York, 1971.

[16] Joseph, Katherine L., "Victim-Offender Mediation: What Social \& Political Factors will Affect its Development", 11: 1 Ohio State Journal On Dispute Resolution, 1996.
[17] Jülich, Shirley \& Thorburn, Natalie, "Sexual Violence and Substantive Equality: Can Restorative Justice Deliver?", 2: 1 Journal of Human Rights and Social Work, June 2017.

[18] Marshall, Tony F., "The Evolution of Restorative Justice in British," 4: 4 European Journal on Criminal Policy and Research, 1996.

[19] _ Restorative Justice: An Overview, Home Office, Information \& Publications Group, London, 1999.

[20] Maurer, Dan, "Military Mediation as Military Justice? Conjectures on Repairing Unit Cohesion in the Wake of Relational Misconduct ", 28: 2 The Ohio State Journal on Dispute Resolution, 2013.

[21] McCold, Paul, "The Recent History of Restorative Justice: Mediation, Circles, and Conferencing", in: Dennis Sullivan and Larry Tifft, Handbook of Restorative Justice: A Global Perspective, Routledge, London and New York, 2006.

[22] Nurhasan, H.M. and Wahyuningsih, Sri Endah, "Restorative Justice Policy in Handling Traffic Accidents in the Legal Area of the Wonosobo Police", 12: 2 Khaira Ummah Legal Journal, June 2017.

[23] Rawls, John, Justice as Fairness: A Restatement, The Belknap Press of Harvard University Press, Cambridge, Massachusetts, 2001.

[24] Reimund, Mary Ellen, "The Law and Restorative Justice: Friend or Foe? A Systemic Look at the Legal Issues in Restorative Justice ", 53 Drake Law Review, 2005.

[25] Schiff, Mara, "Models, Challenges and the Promise of Restorative Conferencing Strategies”, in: Andrew Von Hirsch (et.al.), Restorative Justice and Criminal Justice: Competing or Reconcilable Paradigms?, Hart Publishing, Oxford and Portland, 2003. 
[26] Skelton, Ann \& Batley, Mike, Charting Progress, Mapping the Future: Restorative Justice in South Africa, Restorative Justice Center and Institute for Security Studies, Pretoria, 2006.

[27] Spies, Amanda, "Substantive Equality, Restorative Justice and the Sentencing of Rape Offenders", 29: 3 South African Journal of Criminal Justice, December 2016.

[28] Stancil, Paul, "Substantive Equality and Procedural Justice", 102 Iowa Law Review, 2017.

[29] Stuntz, William J., The Collapse of American Criminal Justice, Harvard University Press, Cambridge, MA, 2011.

[30] United Nations, Promoting Restorative Justice for Children, United Nations, New York, 2016.

[31] UNODC, Handbook on Restorative Justice Programs, United Nations Publication, New York, 2006.

[32] Van Ness, Daniel W. and Strong, Karen Heetderks, Restoring Justice: An Introduction to Restorative Justice, Fourth Edition, Matthew Bender \& Company, Inc., New Providence, NJ, 2010.

[33] Victim Offender Mediation Association (VOMA), "Learn about Victim-Offender Mediation (VOM)", http://www.voma.org/abtvom.shtml [accessed March 17, 2019, 13.00].

[34] Wesson, Murray, "Equality and Social Rights: An Exploration in Light of the South African Constitution", Public Law: The Constitutional and Administrative Law of the Commonwealth, 2007.

[38] 1s and Realities, Ashgate, Hampshire and Burlington, 2007.
[35] Wexler, David, “Therapeutic Jurisprudence and the Criminal Courts", 35: 1 William \& Mary Law Review, 1993.

[36] Whitman, James Q., "Equality in Criminal Law: The Two Divergent Western Roads", 1: 1 Journal of Legal Analysis, Winter 2009.

[37] Zernova, Margarita, Restorative Justice: Idea 